\title{
Een verklaring van arbeidsduur en deeltijdarbeid naar beroep en bedrijfstak
}

Citation for published version (APA):

Groot, L. F. M., \& Heijke, J. A. M. (1989). Een verklaring van arbeidsduur en deeltijdarbeid naar beroep en bedrijfstak. Researchcentrum voor Onderwijs en Arbeidsmarkt, Faculteit der Economische

Wetenschappen. ROA Working Papers No. 2 https://doi.org/10.26481/umarow.1989002

Document status and date:

Published: 01/01/1989

DOI:

10.26481/umarow.1989002

Document Version:

Publisher's PDF, also known as Version of record

\section{Please check the document version of this publication:}

- A submitted manuscript is the version of the article upon submission and before peer-review. There can be important differences between the submitted version and the official published version of record.

People interested in the research are advised to contact the author for the final version of the publication, or visit the DOI to the publisher's website.

- The final author version and the galley proof are versions of the publication after peer review.

- The final published version features the final layout of the paper including the volume, issue and page numbers.

Link to publication

\footnotetext{
General rights rights.

- You may freely distribute the URL identifying the publication in the public portal. please follow below link for the End User Agreement:

www.umlib.nl/taverne-license

Take down policy

If you believe that this document breaches copyright please contact us at:

repository@maastrichtuniversity.nl

providing details and we will investigate your claim.
}

Copyright and moral rights for the publications made accessible in the public portal are retained by the authors and/or other copyright owners and it is a condition of accessing publications that users recognise and abide by the legal requirements associated with these

- Users may download and print one copy of any publication from the public portal for the purpose of private study or research.

- You may not further distribute the material or use it for any profit-making activity or commercial gain

If the publication is distributed under the terms of Article $25 \mathrm{fa}$ of the Dutch Copyright Act, indicated by the "Taverne" license above, 
EEN VERKLARING VAN ARBEIDSDUUR EN DEEL-

TIJDARBEID NAAR BEROEP EN BEDRIJFSTAK

ROA-W-1989/2

L.F.M. Groot en J.A.M. Heijke

RESEARCHCENTRUM VOOR ONDERWIJS EN ARBEIDSMARKT

Faculteit der Economische Wetenschappen

Rijksuniversiteit Limburg

Maastricht, november 1989 


\section{INHOUDSOPGAVE}

Bladzijde

SAMENVATTING i

1. INLEIDING 1

2. HET BEGRIP ARBEIDSVOLUME 3

3. ONTWIKKELING VAN DE ARBEIDSDUUR EN DE MATE VAN DEELTIJDARBEID 6

4. HET SCHATTEN VAN DE ONTBREKENDE GEGEVENS VAN DE ARBEIDSDUUR 8 NAAR BEROEP EN BEDRIJFSTAK

5. EEN VERKLAREND MODEL VAN DE GEMIDDELDE ARBEIDSDUUR 13

$\begin{array}{ll}\text { 6. SIMULATIES } & 19\end{array}$

7. CONCLUSIES EN SAMENVATTING 26

$\begin{array}{ll}\text { LITERATUUR } & 28\end{array}$

BIJLAGE 1

BIJLAGE 2

APPENDIX 


\section{SAMENVATTING}

In dit werkdocument wordt een model ontwikkeld ter verklaring van de arbeidsduur naar beroep en bedrijfstak. In het te schatten model wordt de arbeidsduur naar beroep en bedrijfstak verklaard uit vier variabelen, te weten het percentage vrouwen en het gemiddelde opleidingsniveau (beiden gedifferentieerd naar zowel beroep als naar bedrijfstak), de kapitaalintensiteit en de bezettingsgraad van de produktiecapaciteit (beiden gedifferentieerd naar bedrijfstak). Daarnaast wordt voor elk beroep een beroepen-dummy opgenomen. Het blijkt dat dit arbeidsduurmodel een goede verklaring kan geven van de waargenomen verschillen in de gemiddelde arbeidsduur tussen beroepen en bedrijfstakken. Door middel van een simulatie wordt een prognose gemaakt van de arbeidsduur naar beroep en bedrijfstak voor 1992. 


\section{INLEIDING}

Het Researchcentrum voor Onderwijs en Arbeidsmarkt (ROA) heeft een systeem ontwikkeld voor het maken van middellange-termijnprognoses van het aantal werkzame personen naar beroep en opleiding1. Het uitgangspunt van deze prognoses wordt gevormd door prognoses van het Centraal Planbureau (CPB) van de ontwikkeling van het arbeidsvolume per bedrijfstak. De omrekening van arbeidsvolume naar werkzame personen vindt plaats door gebruik te maken van ramingen van de verhouding per bedrijfstak tussen het aantal werkzame personen en het arbeidsvolume (de zogenaamde P/A ratio's). Hierbij wordt impliciet verondersteld dat de ontwikkeling van de arbeidsduur per beroep vooral bedrijfstak bepaald is.

Deze aanpak moet als onbevredigend worden beschouwd, omdat de arbeidsduur in een aantal gevallen vooral beroepsbepaald is. In het recent ontwikkelde beroepenmodel van het $R O A$ is een eerste stap gezet naar het expliciet maken van de rol van de arbeidsduur binnen het beroepenmode1. Dit is gebeurd door aan te nemen dat de arbeidsduur wel varieert per beroep, maar dat de arbeidsduur naar beroep niet varieert over de bedrijfstakken ${ }^{2}$. Bij deze benadering wordt het effect van deeltijdarbeid (in het vervolg afgekort tot DTA) op het aantal werkzame personen naar beroep impliciet meegenomen. Is bijvoorbeeld de werkgelegenheid voor verpleegkundigen in de periode 19751985 sterk toegenomen vanwege het feit dat veel verpleegkundigen in deeltijdverband zijn gaan werken, dan leidt extrapolatie van deze trend ertoe dat het effect van DTA impliciet wordt meegenomen, hoewel dit proces niet als zodanig is gemodelleerd. In feite wordt dan verondersteld dat dit proces zich in de toekomst zal voortzetten.

Het doel van dit paper is zowel het verbijzonderen van het arbeidsvolume naar bedrijfstakken en beroepen, als het modelleren van het (toekomstige) effect van DTA op de werkgelegenheidsontwikkeling naar bedrijfstak en beroep. Daartoe dient een analyse te worden gemaakt van de snelheid waarmee het proces van DTA zich voltrekt, waarbij wordt onderzocht welke karakteristieken van beroepen en bedrijfstakken van invloed zijn op de mate waarin

1. De Grip, Heijke, Dekker en Groot (1987) en Researchcentrum voor Onderwijs en Arbeidsmarkt (1989).

2. Dekker, De Grip, Heijke (1988). 
in DTA wordt gewerkt.

De opzet van dit paper is als volgt. In paragraaf 2 wordt uiteengezet wat precies wordt verstaan onder de termen arbeidsvolume, werkzame personen en arbeidsduur. In paragraaf 3 wordt een beschrijving gegeven van het proces van arbeidsduurverkorting (in het vervolg afgekort tot ADV) en de ontwikkeling van de mate van DTA. Hierbij worden mogelijke determinanten van beide grootheden geinventariseerd. Er zijn geen gegevens beschikbaar van de arbeidsduur naar beroep en bedrijfstak. In paragraaf 4 worden deze gegevens met behulp van een RAS-procedure geschat uit gegevens van de arbeidsduur naar beroep enerzijds en de arbeidsduur naar bedrijfstak anderzijds. De resultaten van de toegepaste methodiek vormt het startpunt voor het verklarend model voor de arbeidsduur, dat in paragraaf 5 wordt uiteengezet. Hierin wordt geprobeerd de gemiddelde arbeidsduur naar beroepsgroep en bedrijfstak te verklaren uit beroeps- en bedrijfstakspecifieke factoren. Tenslotte worden in paragraaf 6 de gevolgen voor de arbeidsduur doorgerekend van verschillende scenario's voor de toekomstige arbeidsmarktparticipatie. Het paper wordt besloten met enkele conclusies. 


\section{HET BEGRIP ARBEIDSVOLUME}

De beschikbare statistieken verschaffen ten aanzien van de werkgelegenheid verschillende informatie. De Arbeidskrachtentelling (AKT) drukt de werkgelegenheid uit in personen ${ }^{3}$, de Statistiek Werkzame Personen (SWP) in banen en de Nationale Rekeningen (NR) in arbeidsjaren. Sinds er op grote schaal in deeltijd wordt gewerkt is de werkgelegenheid in personen niet meer gelijk aan de werkgelegenheid in banen. Het Centraal Bureau voor de Statistiek 4 drukt de werkgelegenheid daarom uit in arbeidsvolume, waarbij de werkgelegenheid wordt omgerekend naar het aantal personen dat werkt overeenkomstig de uren volledige werktijd. Onder volledige werktijd wordt verstaan het aantal tussen werkgever en werknemers overeengekomen uren, zoals weergegeven in onderstaand schema.

Schema 1. Relaties tussen banen en personen

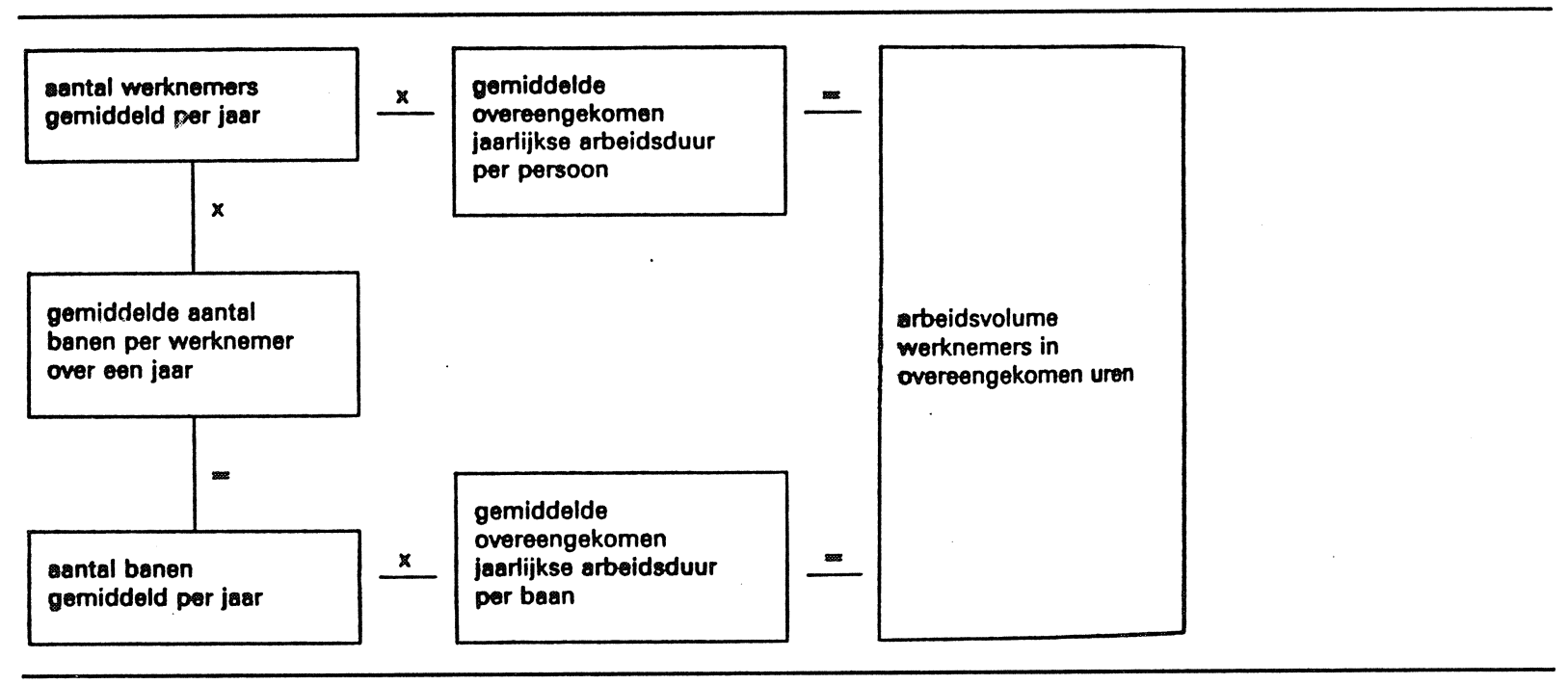

Bron: Bos (1987).

De jaarlijks overeengekomen arbeidsduur per baan is gelijk aan het produkt van het aantal overeengekomen werkweken en de overeengekomen wekelijkse arbeidsduur, verminderd met de extra vrije tijd voor oudere werknemers. Het aantal overeengekomen werkweken is gebaseerd op het aantal werkdagen in een jaar verminderd met het aantal dagen vrijaf wegens erkende feestdagen,

3. In de enquête van de AKT wordt gevraagd naar de normale arbeidsduur en deze kan wegens ziekte, buitengewoon verlof, over- en onderbezetting van de factor arbeid etc. afwijken van de feitelijke arbeidsduur.

4. Zie Bos (1987), blz. 6 e.v. 
verlof en roostervrije tijd voorzover de laatste niet reeds op de wekelijkse duur in mindering is gebracht. Het aantal werkweken wordt gesteld op 52,2 (261 werkdagen) en er zijn 6 feestdagen die vallen op een werkdag. Bij de berekening van de wekelijkse overeengekomen arbeidsduur wordt rekening gehouden met extra vrije uren voor oudere werknemers. Roostervrije tijd, die wordt verstrekt in de vorm van een verkorting van de wekelijkse arbeidsduur, is eveneens behandeld als een aftrekpost.

Het arbeidsvolume uitgedrukt in arbeidsjaren is een jaargemiddelde van het aantal banen herleid tot arbeidsjaren. Een baan is het geheel van werkzaamheden dat door één werknemer bij één bedrijf wordt uitgevoerd. Het arbeidsjaar-equivalent van een baan is bepaald als het quotiënt van de overeengekomen jaarlijkse arbeidsduur behorende bij deze baan en de overeengekomen jaarlijkse arbeidsduur behorende bij een voltijdbaan in de betrokken economische activiteit. Tot de voltijdbanen worden gerekend de arbeidsplaatsen die zijn bezet door werknemers die volgens de met hen gesloten arbeidsovereenkomst een volledige dag- en weektaak bij het bedrijf hebben. Onder deeltijdbanen worden verstaan arbeidsplaatsen bezet door werknemers die volgens de met hen gesloten arbeidsovereenkomst geen volledige dag- of weektaak bij het bedrijf hebben.

De ILO (International Labour Office) definieert DTA als elke arbeid die regelmatig en vrijwillig, gedurende een gedeelte van de dag of van de week wordt verricht en waarvan de duur, in onderlinge overeenstemming tussen de werkgever en de werknemer, merkbaar korter is dan de normale arbeidsduur. De FNV heeft eraan toegevoegd dat DTA arbeid is die naar rato van het kleinere aantal gewerkte uren wordt beloond.

Een verkorting van de contractuele arbeidsduur kan zich in verschillende vormen voordoen. Ten eerste kan de duur van de normale werkweek worden verkort. Ten tweede kan het aantal vakantiedagen of het aantal roostervrije dagen worden uitgebreid. De duur van een volledige werkweek bedraagt thans, bij 25 officiële vakantiedagen en een normaal aantal feestdagen, ca. 35 uur. De feitelijke arbeidsduur wordt daarnaast nog bepaald door de mate van ziekteverzuim en facilitaire voorzieningen zoals buitengewoon-verlofregelingen. Op grond van bovenstaande definities heeft een verkorting van de contractuele arbeidsduur geen gevolgen voor de omrekening van werkzame personen naar arbeids- of mensjaren. Voor de wijze waarop bijzondere categorieën zoals het leerlingwezen, oproepkrachten en ploegendiensten in de arbeidsduurstatis- 
tieken zijn verwerkt wordt verwezen naar Van Ginneken (1988, p. 9 e.v•).

Bovenstaande definities die door het CBS worden gehanteerd, geven ook een indicatie welke factoren wel en welke niet van belang zijn voor de bepaling van de arbeidsduur. De arbeidsduur is een grootheid welke in zijn algemeenheid voornamelijk door twee factoren wordt bepaald, namelijk door het proces van ADV en door de mate waarin in DTA wordt gewerkt. De eerste factor, het proces van ADV, is de laatste jaren in belangrijke mate gedicteerd geweest door de uitkomst van de onderhandelingen tussen de sociale partners. Het proces van $A D V$ is daarom niet geleidelijk verlopen, maar is met horten en stoten gepaard gegaan en lijkt nu tot stilstand te zijn gekomen.

De tweede factor, het fenomeen DTA, kent in tegenstelling tot ADV wel een meer continue ontwikkeling, gezien de geleidelijke toename van het aantal deeltijdwerkers in de laatste decennia. Tot de jaren 70 werd DTA vooral gebruikt als middel om personeel te verkrijgen voor moeilijk vervulbare functies en om pieken in het produktieproces op te vangen. Gezien de krappe arbeidsmarkt waren het vooral (gehuwde) vrouwen die part-time werk verrichtten. De laatste jaren echter is DTA ook een middel ter herverdeling van arbeid geworden. Behalve factoren die werkzaam zijn aan de vraagzijde van de arbeidsmarkt zijn ook aanbodfactoren van invloed geweest op de mate waarin in DTA wordt gewerkt. Met name maatschappelijke emancipatoire ontwikkelingen zorgden voor een toename van het aantal vrouwen op de arbeidsmarkt die een voorkeur hadden om in deeltijdverband betaalde arbeid te verrichten. 0ok in de toekomst zal deze ontwikkeling waarschijnlijk van invloed blijven. 


\section{DE ONTWIKKELING VAN DE ARBEIDSDUUR EN DE MATE VAN DEELTIJDARBEID}

In de periode 1977-1985 is het aantal werkzame personen gestegen, terwij1 het arbeidsvolume uitgedrukt in arbeidsjaren (mensjaren) is gedaald. Dit betekent dat in deze periode sprake is geweest van een toename van het aantal mensen dat in deeltijdverband betaalde arbeid is gaan verrichtten. Tabel 1 laat dit zien.

Tabel 1. Werkzame personen naar geslacht en arbeidsduur, x1000

\begin{tabular}{|c|c|c|c|c|c|}
\hline 1977 & 1979 & 1981 & 1983 & 1985 & \\
\hline \multicolumn{6}{|c|}{ Mannen } \\
\hline Minder dan 15 uur & 27 & 28 & 53 & 52 & 60 \\
\hline 15-24 uur & 56 & 63 & 71 & 73 & 86 \\
\hline 25-34 uur & 101 & 114 & 128 & 129 & 145 \\
\hline 35 uur en meer ${ }^{a}$ & 3299 & 3362 & 3265 & 3104 & 3124 \\
\hline totaal & 3484 & 3567 & 3518 & 3357 & 3414 \\
\hline \multicolumn{6}{|c|}{ Vrouwen } \\
\hline Minder dan 15 uur & 179 & 201 & 242 & 301 & 324 \\
\hline 15-24 uur & 249 & 265 & 398 & 339 & 378 \\
\hline 25-34 uur & 142 & 158 & 159 & 188 & 218 \\
\hline 35 uur en meer ${ }^{a}$ & 753 & 793 & 881 & 822 & 810 \\
\hline totaal & 1322 & 1417 & 1590 & 1650 & 1730 \\
\hline
\end{tabular}

a) Inclusief arbeidsduur onbekend.

Bron: Arbeidskrachtente1ling 1985, CBS, 1987, Staat 12.

In 1985 werkte bij de vrouwen ongeveer de helft minder dan 35 uur, bij de mannen was dit slechts $8 \%$. Het overgrote deel van de deeltijdwerkers is derhalve vrouw. Vanaf 1977 is bij de vrouwen in alle drie urenklassen met minder dan 35 uur een toename van het aantal deeltijdwerkers opgetreden van meer dan $50 \%$, terwijl het percentage vrouwen met een volledige baan met slechts $8 \%$ is toegenomen. Bij de mannen is de stijging van het aantal deeltijdwerkers iets minder geprononceerd, maar daar staat tegenover dat het aantal mannen met een volledige baan licht is afgenomen. In het totaalbeeld 
is de stijging van het aantal werkzame personen volledig herleidbaar op het grotere aantal vrouwen dat betaalde arbeid is gaan verrichten.

Hoewel er tweemaal zoveel mannen betaalde arbeid verrichten dan vrouwen, is ook absoluut gezien het aantal in deeltijd werkende vrouwen veel groter dan bij mannen. In 1985 waren er vier maal zoveel vrouwen dan mannen werkzaam in deeltijdverband. Het ligt dus voor de hand in de verklaring van de gemiddelde arbeidsduur onder andere het percentage vrouwen werkzaam in het desbetreffende beroep als verklarende variabele op te nemen. Daarnaast is het voor de prognose van belang rekening te houden met de verandering in het percentage vrouwen in het arbeidsaanbod. Immers, de nog steeds stijgende participatiegraad van vrouwen zal ook in de toekomst van invloed zijn op de gemiddelde arbeidsduur.

Los van de effecten op de arbeidsduur die uitgaan van de mate waarin vrouwen participeren op de arbeidsmarkt zijn er andere matschappelijke ontwikkelingen van invloed op de arbeidsduur (zie 0.a. Hessemans (1988), Rapport inzake werkgelegenheid en arbeidsduur (1981), Arbeidsduur nader bekeken (1983) en Rapportage Arbeidsmarkt (1986)). Aan werkgeverszijde is grotere vraag ontstaan naar mensen die in deeltijdverband willen werken, voornamelijk om in de grotere behoefte aan flexibiliteit te voorzien die is ontstaan ten gevolge van de toenemende kapitaalintensiteit en de onzekere economische situatie. Met name de volgende vormen van DTA kunnen de flexibiliteit verhogen: een korter aantal uren per dag, de mini-shift (korte ploegendienst), het min-max-systeem (waarbij een minimum en een maximum aantal werkuren wordt afgesproken), het afroepcontract, duobanen (samen verantwoordelijk voor één voltijdsbaan), het "kom als je wilt" systeem en meerdere personen met één arbeidscontract (zie voor een meer uitgebreide uiteenzetting Delsen (1986)). 
4. HET SCHATTEN VAN DE ONTBREKENDE GEGEVENS VAN DE ARBEIDSDUUR NAAR BEROEP EN BEDRIJFSTAK

De gegevens die voor het beroepenmodel van het ROA worden gebruikt zijn ontleend aan de Arbeidskrachtentellingen van het CBS. De gegevens van beroepen luiden in werkzame personen. De bedrijfstakgegevens van het CPB, die het uitgangspunt vormen voor de beroepenprognose van het ROA, zijn daarentegen gebaseerd op de Nationale Rekeningen van het CBS. Deze gegevens zijn uitgedrukt in arbeidsvolume. Bij het beroepenmodel van het ROA vindt dus niet alleen een omrekening plaats van de werkgelegenheid in de bedrijfstakken naar beroepen, maar worden tegelijkertijd grootheden in arbeidsvolume omgezet in grootheden in personen.

Zoals opgemerkt in paragraaf 2 wordt onder arbeidsvolume verstaan het aantal werkzame personen dat in een jaar aanwezig is, gewogen met het in dat jaar gewerkte deel van de normale werktijd bij een volledige baan. Deze grootheid staat dus onder invloed van zowel de in- en uitstroom uit het bestand werkzame personen als de mate waarin in deeltijd wordt gewerkt. Voor het omrekenen van het arbeidsvolume naar het aantal werkzame personen op een bepaald tijdstip moet dus met deze factoren rekening worden gehouden. Er zal echter worden aangenomen dat de jaarlijkse in- en uitstroom van het bestand werkzame personen geen storende invloed heeft ${ }^{5}$, zodat alleen met de mate waarin in deeltijd wordt gewerkt behoeft te worden rekening gehouden. Om op basis van de CPB-prognoses van het arbeidsvolume per bedrijfstak prognoses te kunnen opstellen van het aantal werkzame personen per beroep in een bedrijfstak moet dus een prognosemodel worden ontwikkeld van de mate warin per beroep in een bedrijfstak in deeltijd wordt gewerkt.

De gegevens over de gewerkte arbeidsduur naar beroep en bedrijfstak die voor de ontwikkeling van dit model nodig zijn, zijn echter niet direct beschikbaar. Wel konden door het CBS gegevens ter beschikking worden gesteld over (a) de verdeling van het aantal werkzame personen in beroepen, volgens een drie-digit indeling, naar acht (wekelijkse) arbeidsduurklassen, (b) de verdeling van het aantal werkzame personen in bedrijfstakken, volgens een twee-digit indeling, naar dezelfde acht arbeidsduurklassen en (c) de verdeling van het aantal werkzame personen naar beroep over bedrijfstakken. In

5. Er treedt alleen een storende invloed op in zoverre de gemiddelde arbeidsduur van de instroom significant verschilt van die van de uitstroom. 
feite zijn daarmee de randen van een drie-dimensionale matrix bekend (beroep $x$ bedrijfstak $x$ arbeidsduur) en voor een deel het binnenwerk (de verdeling van het aantal werkzame personen naar beroep over bedrijfstakken).

Op basis van bovengenoemde gegevens en door toepassing van een RAS-procedure kan de gemiddelde arbeidsduur per beroep in een bedrijfstak worden bepaald. Met de RAS-procedure worden de waarden van de cellen zodanig aangepast dat de rij- en kolomtotalen bij benadering kloppen. Het resultaat is een complete matrix van arbeidsduur naar beroep en naar bedrijfstak. Deze gegevens zullen het uitgangspunt vormen voor het schatten van een vergelijking voor de gemiddelde arbeidsduur in een beroep in een bedrijfstak.

De RAS-methode is ontwikkeld in het kader van de input-output analyse, waarbij meestal wel een complete matrix uit het verleden bekend was, tezamen met de sectorale input- en output-totalen voor het prognosejaar, maar niet het binnenwerk van deze matrix. Met de RAS-methode werd dit binnenwerk dan zodanig geschat dat voldaan werd aan de input- en output-totalen.

Er zal nu worden aangegeven welke informatie in ons geval door de RASprocedure moet worden gegenereerd. Het doel van deze exercitie is het schatten van de arbeidsduur naar beroep en bedrijfstak. Gaat men uit van 84 beroepen, 23 bedrijfstakken en 8 arbeidsduurklassen, dan zijn er in totaal $84 * 23 * 8(=15456)$ cellen die behoren tot het binnenwerk. De randtotalen $z i j n$ :

- $84 * 8$ beroepstotalen;

- $23 * 8$ bedrijfstaktotalen;

- 8 generale totalen (de verdeling van de totale beroepsbevolking over de 8 arbeidsduurklassen).

Dit zijn in totaal 856 bekenden tegenover de 15456 onbekenden. Bij het toepassen van de RAS-procedure moeten niet alleen de randtotalen van de te schatten matrix bekend zijn, maar strikt genomen ook het binnenwerk van een overeenkomstige matrix (eventueel uit een ander jaar) dat kan dienen als startpunt van de RAS-iteraties ${ }^{6}$. Omdat er geen complete matrix van arbeidsduur naar beroep naar bedrijfstak voorhanden is moeten aanvullende

6. Indien het binnenwerk en de randtotalen van het aantal werkzame personen naar urenklassen voor 1985 bekend zijn en bovendien de randtotalen voor het prognosejaar bekend zijn, dan is alle informatie aanwezig om het binnenwerk voor het prognosejaar te schatten. De informatie van de jaren vóór 1985 hoeft dus niet, maar kan wel worden gebruikt. 
veronderstellingen worden gemaakt:

- De arbeidsduur voor elke bedrijfstak afzonderlijk geldt voor alle beroepen binnen deze bedrijfstak. Dat wil zeggen dat de sectorale verdeling van de arbeidsduur wordt opgelegd aan de hele matrix van beroep*bedrijfstak. Dit wordt de bedrijfstakhypothese genoemd.

- De arbeidsduur voor elk beroep afzonderlijk geldt voor alle bedrijfstakken waarin dit beroep vertegenwoordigd is. Dat wil zeggen de verdeling van de arbeidsduur voor de beroepen wordt opgelegd aan de hele matrix van beroep*bedrijfstak. Dit wordt de beroephypothese genoemd.

Er wordt nu als volgt te werk gegaan. Eerst wordt de bedrijfstakhypothese toegepast, waarbij de arbeidsduurverdeling per bedrijfstak wordt opgelegd aan alle beroepen binnen deze bedrijfstak. De horizontale optelling (over de beroepen) strookt dan met het definitieve rijtotaal (de definitieve rij-en kolomtotalen zijn bekend). De verticale optelling (over de bedrijfstakken) zal echter niet stroken met het definitieve kolomtotaal. De eerste stap (iteratie) in de RAS-procedure is nu om voor elke kolom (beroep) het feitelijke kolomtotaal te vermenigvuldigen met de verhouding tussen het definitieve en het feitelijke kolomtotaal zodat de verticale optelling klopt. Tevens worden alle verschillen tussen de definitieve en de feitelijke totalen opgeteld en gehanteerd als matstaf hoe goed de hypothese zich verhoudt tot de werkelijkheid (de definitieve totalen).

Als gevolg van de vermeniguuldiging strookt nu wel de verticale, maar niet meer de horizontale optelling. De verschillen tussen de definitieve en de feitelijke totalen worden weer opgeteld en bij een convergerende RASprocedure zal deze som van verschillen met elke stap kleiner worden. Analoog aan de eerste stap wordt weer de vermenigvuldiging over de rijen gemaakt zodat de rijtotalen overeenstemmen. Deze handelingen worden herhaald totdat de som van verschillen niet meer verder afneemt. Dezelfde procedure wordt doorlopen wanneer de tweede hypothese aan het binnenwerk van de matrix wordt opgelegd.

De procedure die hierboven is beschreven staat bekend als het "biproportional constrained matrix problem"7. In matrix-notatie kunnen alle stappen overzichtelijk worden weergegeven. Zij A de matrix die het startpunt van de RAS-procedure vormt. De matrix A wordt door een van bovenstaande

7. Zie Bacharach (1970), blz.45 e.v. 
hypothesen gegenereerd. $Z i j$ u en $v$ vectoren van de definitieve rij- en kolomtotalen (deze zijn de "constraints") en $i$ de eenheids-vector. Dan kan het probleem gedefinieerd worden als:

$A^{*} \geq 0$;

$A^{*} i=u, i A^{*}=v$;

$A^{*}=\lim _{t \rightarrow \infty}\left\langle R^{t}\right\rangle A\left\langle S^{t}\right\rangle$

waarbij $A^{*}$ de oplossing van de RAS-procedure, 〈〉 een diagonaalmatrix en $t$ het aantal iteraties voorstelt. De matrices $\mathrm{R}^{\mathrm{t}}$ en $\mathrm{S}^{\mathrm{t}}$ bevatten de verhoudingsgetallen tussen de berekende en de definitieve rij-en kolomtotalen in ronde $t$.

De eerste conditie wil zeggen dat de resulterende matrix niet-negatief (semipositief definiet) moet zijn. De tweede conditie wil zeggen dat de berekende rij- en kolomtotalen van de oplossing $A^{*}$ gelijk moeten zijn aan de definitieve rij- en kolomtotalen. De derde conditie geeft het convergentiecriterium weer, dat wil zeggen dat wanneer de oplossing na een aantal iteraties is bereikt de oplossing niet meer verandert door verder te itereren. Dit betekent dat de diagonaal-elementen $r_{j}$ van $R^{t}$ en $s_{k}$ van $s^{t}$ allen zeer dicht rond de waarde 1 liggen. Tijdens de oneven stappen worden de rijtotalen bijgesteld en tijdens de even stappen de kolomtotalen, volgens:

$$
\begin{aligned}
& A^{2 t+1}=\left\langle r^{t+1}\right\rangle A^{2 t} \\
& A^{2 t+2}=A^{2 t+1}\left\langle s{ }^{t+1}\right\rangle=\left\langle r^{t+1}\right\rangle A^{2 t}\left\langle s^{t+1}\right\rangle \\
& \text { warbij } \\
& r_{i}{ }^{t+1}=u_{j} / \Sigma_{j} a_{i j} 2 t \\
& s_{j}{ }^{t+1}=v_{j} / \Sigma_{i} a_{i j}{ }^{2 t+1}
\end{aligned}
$$

De elementen $r_{j}$ en $s_{j}$ zijn dus de vermeniguuldigingsfactoren in de desbetreffende iteratie en geven de verhoudingen weer tussen de definitieve en de feitelijke rij- en kolomtotalen. Een waarde gelijk aan één wil zeggen dat de feitelijke en de definitieve totalen aan elkaar gelijk zijn.

Door Bacharach (1970, blz. 47 e.v•) zijn de voorwaarden afgeleid waaronder de RAS-procedure leidt tot een unieke oplossing en onder welke voorwaarden het proces convergeert. Een unieke oplossing impliceert derhalve dat het niet uitmaakt met welke hypothese (de bedrijfstak- of de beroephypothese) 
de RAS-procedure wordt gestart. Voldoende voorwaarde voor beide eisen, een unieke oplossing en convergentie, is dat de matrix A niet "disconnected" is. Een matrix $A$ is disconnected als voor $i \in I, j \in J^{\prime}$ en voor $i \in I^{\prime}, j \in J$ geldt $a_{i j}=0$. Men krijgt dan een matrix van de vorm

$\left|\begin{array}{ll}A_{I J} & A_{I J}{ }^{\prime} \\ A_{I}{ }^{\prime} J & A_{I}{ }^{\prime} J^{\prime}\end{array}\right|=\left|\begin{array}{cc}A_{I J} & 0 \\ 0 & A_{I}{ }^{\prime} J\end{array}\right|$

Voldoende voorwaarde is dus dat de submatrices binnen de matrix die voor de RAS-procedure als startpunt dient ongelijk zijn aan 0.

Het blijkt dat de beroephypothese (de arbeidsduur voor elk beroep afzonderlijk geldt voor alle bedrijfstakken waarin dit beroep is vertegenwoordigd) de werkelijkheid beter benadert dan de bedrijfstakhypothese (de arbeidsduur is bedrijfstak-bepaald). Dit blijkt uit de geringere discrepantie tussen de definitieve en de feitelijke randtotalen bij het opleggen van de beroephypothese dan bij het vertrekken vanuit de bedrijfstakhypothese. Overigens zijn bij een groot aantal iteraties van de RAS-procedure de verschillen in discrepanties tussen de definitieve en de feitelijke randtotalen onder beide hypothesen klein. 


\section{EEN VERKLAREND MODEL VAN DE GEMIDDELDE ARBEIDSDUUR}

Met behulp van de RAS-procedure is de beschikking verkregen over een complete matrix van beroep $x$ bedrijfstak $x$ arbeidsduur. Door middel van een regressie-analyse zal nu worden geprobeerd de ontwikkeling van de arbeidsduur naar beroep en bedrijfstak te analyseren. Het te schatten model van de arbeidsduur moet kunnen worden gebruikt voor het opstellen van middellangetermijnprognoses van de werkgelegenheid in personen naar beroep. Dit betekent dat het alleen zin heeft om in het model verklarende variabelen op te nemen die in de tijd variëren en naar de toekomst kunnen worden doorgetrokken.

De te verklaren variabele is de gemiddelde arbeidsduur per week in een beroep in een bedrijfstak, gedeeld door de normale arbeidsduur per week in de desbetreffende bedrijfstak, bij volledige werktijd. In de desbetreffende regressievergelijking wordt van dit verhoudingscijfer de logaritme genomen ten einde te voorkomen dat dit cijfer negatieve waarden aanneemt.

Als verklarende variabelen worden de volgende grootheden opgevoerd:

- Het percentage vrouwen in het beroep in de bedrijfstak. In 1985 werd ongeveer $80 \%$ van de deeltijdbanen bezet door vrouwen, wat betekent dat de helft van alle werkzame vrouwen een deeltijdbaan bezet. Daarom mag worden verwacht dat naarmate het percentage vrouwen in een beroep in een bedrijfstak groter is, de arbeidsduur korter zal zijn.

- Het gemiddelde opleidingsniveau (in jaren) van de werkzame personen in een beroep in een bedrijfstak. Naarmate het opleidingsniveau van een beroep in een bedrijfstak hoger is, zal naar verwachting langer worden gewerkt ten einde het geïnvesteerde menselijke kapitaal zo goed mogelijk te benutten. De veronderstelling dat hooggeschoolde werknemers minder in deeltijd werken, kan worden ondersteund met inzichten ontleend aan de theorie van het menselijk kapitaal. Hoger geschoolden zullen de gemaakte kosten (zowel de directe uitgaven aan onderwijs als het gederfde arbeidsinkomen tijdens het volgen van volledig dagonderwijs) en de geleverde (psychische) inspanning willen terugverdienen tijdens de beroepsloopbaan. De gemiddeld hogere loonvoet van hoger opgeleiden stelt ze hiertoe ook in staat. De hogere loonvoet betekent tevens dat de 'opportunity costs' van het werken in deeltijd (dus van meer vrije tijd) hoger zullen zijn voor hoger opgeleiden. Bovendien zal van de werkgeverszijde een voorkeur bestaan om de relatief hoog geschoolde en dure werknemers, waarin zij 
vaak zelf via aanvullende scholing hebben geïnvesteerd, full-time te laten werken.

- De kapitaalintensiteit van de bedrijfstak. De veronderstelling is dat naarmate de kapitaalintensiteit hoger is, langer zal worden gewerkt ten einde de aanwezige kapitaalvoorraad zo intensief mogelijk te benutten. Om het dure machinepark zo optimaal mogelijk te laten functioneren zal de wekelijkse arbeidsduur dus langer en het aantal deeltijdwerkers lager zijn naarmate de bedrijfstak kapitaalintensiever is. Bij de arbeidsintensieve bedrijfstakken zoals de horeca, de detailhandel en het onderwijs zullen de aard van de werkzaamheden zich beter lenen voor het verrichten van arbeid in part-time.

- De bezettingsgraad van de produktiecapaciteit van de bedrijfstak. Naarmate de bezettingsgraad hoger is, worden de grenzen van de produktiecapaciteit dichter benaderd. Deze grenzen zullen zijn afgestemd op de afzet die men op lange termijn realiseerbaar acht. Men zal bij een hogere bezettingsgraad daarom liever overgaan tot het verlengen van de arbeidsduur dan het aantrekken van nieuwe arbeidskrachten die bij tegenvallende afzetresultaten weer zouden moeten worden ontslagen. Omdat in bepaalde bedrijfstakken de produktiecapaciteit zeer moeilijk is te bepalen, zal een grootheid worden genomen die proportioneel mee fluctueert met de mate van bezetting van de produktiecapaciteit (BEZ), namelijk de gerealiseerde toegevoegde waarde (TW) gerelateerd aan het vijfjaarlijks voortschrijdende gemiddelde van de toegevoegde waarde

$$
B E Z=T W_{t} / \sum_{j=-2}^{+2}=T W_{t+j}
$$

- Er zijn nog andere factoren die van invloed kunnen zijn op de arbeidsduur. Door Van Ginneken (1980) worden onder andere genoemd het uurloon, de loonquote, de arbeidsproduktiviteit, het functieniveau, de aanwezigheid van ploegendiensten, de regio, de bedrijfstijd, het aandeel van het midden- en kleinbedrijf in de sectorale werkgelegenheid en de werkgelegenheidsgroei. Het voornaamste probleem is dat het CPB geen prognoses opstelt van deze variabelen, met uitzondering van de arbeidsproduktiviteit (deze is evenwel nauw gerelateerd aan de kapitaalintensiteit in het te schatten model). Bovendien kunnen er aanzienlijke multicolliniariteitsproblemen optreden bij het simultaan opnemen van meerdere bedrijfstak- en beroepsvariabelen: bijv. het opleidingsniveau en het functieniveau zijn sterk met elkaar gecorreleerd. Om het effect van deze weggelaten variabelen toch in het model te incorpereren worden in de te schatten vergelijkingen beroependummy's opgenomen en geëvalueerd of zij bijdragen aan de verklaringskracht van het model. 
De te schatten regressievergelijking wordt dan :

$\ln (\mathrm{HBS} / \mathrm{HS})=\Sigma \mathrm{b} a_{b} \mathrm{DB}+\mu \mathrm{FBS}+\beta \mathrm{ONBS}+\tau \mathrm{KIS}+\theta \mathrm{BEZ}$,

met verwachting: $\beta, \tau, \theta>0$,

$\mu<0$,

waarin:

HBS = arbeidsduur in beroep $B$ en bedrijfstak $S$ in uren per week;

$H S=$ normale arbeidsduur per bedrijfstak in uren per week;

$\mathrm{DB}=$ dummy-variabele, bij beroep $\mathrm{B} D \mathrm{DB}=1$, elders $\mathrm{DB}=0$;

ONBS = gemiddeld aantal jaren genoten onderwijs in een beroep in een bedrijfstak;

KIS = investeringen in een bedrijfstak over afgelopen vijf jaar gedeeld door de toegevoegde waarde over deze periode, beide in constante prijzen;

BEZ = toegevoegde waarde van een bedrijfstak gedeeld door de gemiddelde toegevoegde waarde van die bedrijfstak over afgelopen drie en komende twee jaar, in constante prijzen, als benadering voor de bezettingsgraad;

FBS = aandeel vrouwen in een beroep in een bedrijfstak;

$B, S$ = beroep, bedrijfstak.

Door middel van het modelleren van beroependummies voor elk beroep wordt rekening gehouden met het feit dat voor beroepen met dezelfde structuur (FBS, ONBS, KIS, BEZ) toch verschillende arbeidsduren kunnen voorkomen. Dit model staat in de literatuur bekend als het Dummy Variable Model (zie o.a. Judge (1980)).8

In tabel 2 zijn de gemiddelden en de minimum- en maximumwaarden van de regressievariabelen vermeld. De gegevens hebben betrekking op het jaar 1985. Gemiddeld is de arbeidsduur vanwege deeltijdarbeid ongeveer $10 \%$ korter dan de normale arbeidsduur. Het percentage vrouwen in de actieve beroepsbevolking is $34 \%$, in sommige beroep-bedrijfsrak combinaties zijn geen vrouwen aanwezig, in andere zijn alleen maar vrouwen aanwezig. De kapitaalintensiteit varieert van 0,03 (voor de zakelijke dienstverlening en de overige dienstverlening) tot 0,51 (voor de zee-en luchtvaart). De bezettingsgraad varieert slechts zeer weinig, van 0,88 (voor de 01ie-raffinage

8 Voor een meer uiteengebreide uiteenzetting van het model zie de Appendix. 
sector) tot 1,06 (voor de delfstofwinning). Het gemiddelde opleidingsniveau is 11 jaar $^{9}$, degenen met een academische opleiding hebben 18 jaar onderwijs genoten.

De vergelijking wordt met behulp van OLS geschat door middel van een crosssection over 84 beroepen (twee-digit, CBS/ISCO beroepenclassificatie, zie bijlage 1) en 23 bedrijfstakken (CPB indeling). De 84 beroepen en 23 bedrijfstakken leveren in principe 1932 combinaties, echter slechts in 1031 combinaties zijn mensen werkzaam. Deze waarnemingen worden bij de regressie gewogen naar rato van het aantal werknemers werkzaam in die combinatie van beroep en sector.

Tabe1 2. Overzicht van de regressie-variabelen

\begin{tabular}{llll}
\hline VARIABELE & GEMIDDELDE & MINIMUM & MAXIMUM \\
\hline HBS/HS & & & \\
FBS & 0,898 & 0,33 & 1,08 \\
KIS & 0,340 & 0,00 & 1,00 \\
BEZ & 0,068 & 0,03 & 0,51 \\
ONBS & 1,000 & 0,88 & 1,06 \\
& 5,002 & 0,00 & 12,00 \\
\hline
\end{tabular}

De schattingsresultaten zijn weergegeven in tabel 3A. In deze tabel zijn niet alle beroependumm's weergegeven, maar alleen die van beroepen met een arbeidsduur die veel korter is dan de normale arbeidsduur in de bedrijfstakken waar het beroep wordt uitgeoefend. Voor een volledig overzicht van de beroependummy's wordt verwezen naar tabel $3 \mathrm{~B}$ in bijlage 2 .

Uit de schattingsresultaten volgt dat het percentage vrouwen in een beroep in een bedrijfstak een significant negatief effect heeft op de arbeidsduur. Het gevonden effect is zeer groot. Als het aandeel van vrouwen in een beroep in een bedrijfstak $100 \%$ is, wordt er, ceteris paribus, $23 \%$ korter gewerkt

9. Bij de schattingen is basisonderwijs (gelijk aan zes jaar onderwijs) op nul gesteld, zodat het gemiddelde opleidingsniveau gelijk is aan 5 . 
dan de normale werktijd bij een volledige baan10. Als men uitgaat van een normale arbeidsduur van 37,5 uur per week dan is de reductie van de arbeidsduur gelijk aan 8,6 uur. Dit komt aardig overeen met wat a-priori op basis van tabel 1 in de inleiding kon worden verwacht. Gesteld dat de helft van de vrouwen DTA verricht en gesteld dat zij die in deeltijd werken gemiddeld 15 uur per week minder betaalde arbeid verrichten dan voltijds werkende vrouwen (zie tabel 1), dan zou het totale effect van een stijging van het percentage vrouwen van 0 naar $100 \%$ gelijk moeten zijn aan $0.5 *(-15$ uur) $=-7.5$ uur.

De variabele opleidingsniveau is eveneens, significant en heeft het verwachte, positieve, teken. Het effect van veranderingen in het opleidingsniveau op de arbeidsduur is echter gering.

De kapitaalintensiteit en de bezettingsgraad van de produktiecapaciteit zijn beide niet significant en hebben bovendien een niet verwacht, negatief, teken.

In de tabel zijn, zoals reeds opgemerkt, de beroepspecifieke effecten op de arbeidsduur weergegeven voor de beroepen met een arbeidsduur die veel korter is dan normal. Uit het gegeven overzicht blijkt bijvoorbeeld dat een werknemer die tot de beroepsgroep leerkrachten behoort $30 \%$ korter werkt dan de normale arbeidsduur. Dit komt natuurlijk door het grote aantal deeltijd dienstverbanden. Voor het huishoudelijke en het verzorgend personeel en voor huisbewaarders en schoonmaakpersoneel zijn deze percentages respectievelijk $39 \%$ en $55 \%$.

10. In een semi-logarithmische vergelijking kunnen de coëfficienten worden geïnterpreteerd als relatieve veranderingen.

Dit is als volgt in te zien:

$\ln (y)=\alpha+\beta x$, dus $\delta \ln (y) / \delta x=(\delta \ln (y) / \delta y)(\delta y / \delta x)=(\delta y / y) / \delta x=\beta$. De coefficient $\beta$ geeft derhalve de relatieve verandering van de afhankelijke variabele $y$ door verandering van de verklarende variabele $x$ weer. 
Tabe1 3A. Schattingsresultaat arbeidsduurmodel

\begin{tabular}{|c|c|c|c|}
\hline $\begin{array}{ll}\mathrm{R}^{2} & 0,918 \\
\mathrm{SE} & 0,478\end{array}$ & & & \\
\hline Variabele & coëfficiënt & t-waarde & \\
\hline $\begin{array}{l}\text { KIS } \\
\text { FBS } \\
\text { ONBS } \\
\text { BEZ }\end{array}$ & $\begin{array}{r}-0,012719 \\
-0,232143 \\
0,013536 \\
-0,211602\end{array}$ & $\begin{array}{r}-0,336 \\
-10,136 \\
3,420 \\
-0,989\end{array}$ & \\
\hline Dummy & coëfficiënt & t-waarde & \\
\hline $\begin{array}{l}\text { DB10 } \\
\text { DB14 } \\
\text { DB15 } \\
\text { DB26 } \\
\text { DB37 } \\
\text { DB42 } \\
\text { DB43 } \\
\text { DB44 }\end{array}$ & $\begin{array}{l}-0,304 \\
-0,418 \\
-0,300 \\
-0,154 \\
-0,155 \\
-0,104 \\
-0,394 \\
-0,552\end{array}$ & $\begin{array}{r}-7,54 \\
-8,47 \\
-5,45 \\
-5,61 \\
-6,07 \\
-4,29 \\
-13,03 \\
-23,15\end{array}$ & $\begin{array}{l}\text { Leerkrachten. } \\
\text { Musici, toneelspelers e.a. } \\
\text { Beroepssportlieden e.d. } \\
\text { Post-distributiepersoneel } \\
\text { Winkelbedienden e.a. verkopers } \\
\text { Koks, kelners, buffetbedienden } \\
\text { Huish. en verzorgend personeel n.e.g. } \\
\text { Huisbewaarders, schoonmakpersoneel }\end{array}$ \\
\hline
\end{tabular}




\section{SIMULATIES}

Bij het opstellen van prognoses staan in principe twee wegen open. Bij het beschikbaar zijn van prognoses van de verklarende variabelen voor het prognosejaar kan aan de hand van het geschatte model in paragraaf 5 een prognose worden gemaakt van de afwijking van de arbeidsduur naar beroep en bedrijfstak in 1992 ten opzichte van de dan geldende normale arbeidsduur. Wanneer geen informatie voor handen is over de omvang van de verklarende variabelen voor het prognosejaar dan is het maken van simulaties een manier om enig inzicht te krijgen in mogelijke toekomstige ontwikkelingen. Bij simulaties worden verschillende veronderstellingen (varianten) gemaakt ten aanzien van de ontwikkeling van de verklarende variabelen.

De simulatie die in deze paragraaf zal worden uitgevoerd draagt evenwel elementen van beide benaderingen in zich. Voor de kapitaalintensiteit gebruiken wij de prognoses van het Centraal Planbureau en voor het opleidingsniveau naar beroep en naar bedrijfstak de prognoses van het ROA. Het percentage vrouwen zal worden gebaseerd op zowel eigen extrapolaties, waarbij rekening wordt gehouden met de mogelijkheid van 'verzadiging' van het percentage vrouwen in bepaalde beroepen en bedrijfstakken, als op elders uitgevoerd onderzoek.

Op basis van berekeningen uitgevoerd door Op de Beke (1988) kan worden afgeleid dat het landelijke percentage vrouwen in de actieve beroepsbevolking naar verwachting zal stijgen van $33,6 \%$ in 1985 tot $36,3 \%$ in 1992 . Het is niet aannemelijk dat de groei van het percentage vrouwen zich in alle bedrijfstakken en in alle beroepen in gelijke mate zal voordoen. In sommige beroepen zijn overwegend vrouwen werkzaam (zoals bij winkelbedienden en verpleegsters), in andere zijn vrouwen ongeveer rechtevenredig vertegenwoordigd (bijvoorbeeld bij onderwijzers en leerkrachten) of zwaar ondervertegenwoordigd (in leidinggevende functies en in de industriële en ambachtelijke beroepen). Het is mogelijk dat het percentage reeds werkzame vrouwen van invloed is op de verdere groei van de fractie vrouwelijke beroepsbeoefenaren. Bij kraamverzorgsters en mondhygiënistes (percentage vrouwen is $100 \%$ ) en bij doktersassistentes en secretaressen, typisten en telexisten (98,7 resp. $95,2 \%$ ) kan het percentage vrouwen nauwelijks verder stijgen. In deze, maar ook in veel andere beroepen waar relatief veel vrouwen werkzaam zijn, kunnen "verzadigings-verschijnselen" gaan optreden, in die zin dat de stijging van de fractie vrouwelijke beroepsbeoefenaren hier kleiner zal zijn dan het 
landelijke stijgingspercentage. Daartegenover moeten dan wel meer dan proportionele stijgingen staan in andere beroepen. In onderstaande figuur is deze situatie in beeld gebracht.

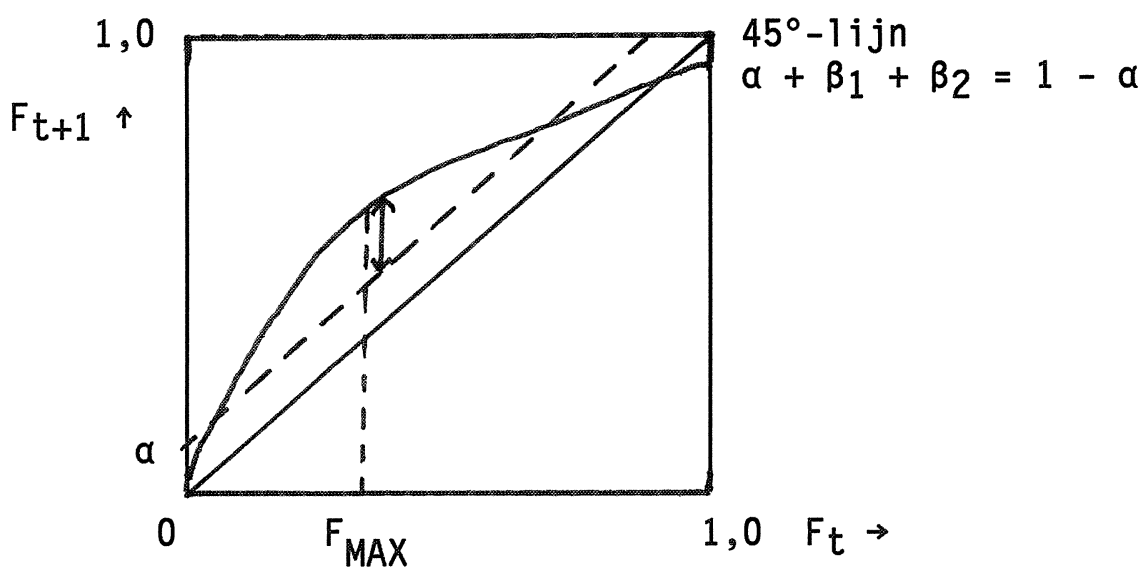

Op de horizontale as staat het percentage vrouwen in de uitgangssituatie $\left(F_{t}\right)$. Op de verticale as staat het percentage vrouwen in het prognosejaar $\left(F_{t+1}\right)$. De $45^{\circ}-1$ ijn geeft de situatie weer waarbij het percentage vrouwen voor alle beroepen en bedrijfstakken niet meer zal veranderen. De gestippelde lijn, evenwijdig aan de $45^{\circ}-1 i j n$, geeft de hypothetische situatie weer waarbij in alle beroepen en bedrijfstakken de stijging van het percentage vrouwen gelijk is aan het landelijke stijgingspercentage. De getrokken curve tenslotte, met de "buik" links van het midden, geeft de situatie van "verzadiging" weer. In beroepen en bedrijfstakken waar het percentage vrouwen zeer hoog is zal de stijging volgens deze curve kleiner zijn dan het landelijke stijgingspercentage (aangegeven door de afstand tussen de gestippelde lijn en de $\left.45^{\circ}-1 i j n\right)$. Dit komt overeen met de bevindingen van Van Mourik en Siegers (1988, p.735) in een onderzoek naar de ontwikkeling van de beroepssegregatie tussen mannen en vrouwen in het tijdvak 1971-1985. Zij constateren dat mannen in steeds sterkere mate intreden in beroepen waar vrouwen oververtegenwoordigd zijn. Bovendien blijkt slechts een klein deel van de toename van de vrouwelijke beroepsbevolking in te treden in beroepen waar mannen oververtegenwoordigd zijn, wat correspondeert met de uiterste linkerzijde van bovenstaande curve. De grootste stijging in het percentage vrouwen zal derhalve naar verwachting plaatsvinden rond het middengedeelte, waar noch sprake is van "verzadiging" noch van enige "drempelwerking" in het aanstellen van vrouwen. 
De hierboven geschetste ontwikkeling betreft slechts een vereenvoudigde werkhypothese met betrekking tot de extrapolatie van het percentage vrouwen. Het geschetste verband kan worden benadert met een tweede graads polynoom:

$F_{t+1}=\alpha+\beta_{1} F_{t}+\beta_{2} F_{t}{ }^{2}$

waarbij:

$\mathrm{F}_{\mathrm{t}+1}=$ het percentage vrouwen in het prognosejaar;

$F_{t}=$ het percentage vrouwen in het basisjaar;

$\alpha, \beta=$ coëfficienten.

Er zijn echter wel enkele voorwaarden waaraan de vergelijking moet voldoen. Ten eerste moet gelden dat de landelijke stijging van het percentage vrouwen in de beroepsbevolking gelijk is aan de met de werkgelegenheidsaandelen gewogen stijging van het percentage vrouwen in de afzonderlijke beroepen en bedrijfstakken:

$\Delta F=\Sigma_{b} \Sigma_{s}\left(F_{t+1}-F_{t}\right) A_{b s}$

waarbij:

$\Delta \mathrm{F}=$ landelijke stijging van het percentage vrouwen in de beroepsbevolking; $A_{b s}=$ het werkgelegeheidsaandeel van beroep $b$ in bedrijfstak $s$

$\left(\Sigma_{b} \Sigma_{s} A_{b s}=1\right)$;

Omdat het gemiddelde percentage vrouwen in de beroepsbevolking $\bar{F}$ gelijk is aan $\Sigma_{b} \Sigma_{s} F_{t} A_{b s}$ geeft substitutie van vergelijking (6.1) in (6.2):

$$
\begin{aligned}
& \Delta F=\Sigma_{b} \Sigma_{s}\left(F_{t+1}-F_{t}\right) A_{b s}=\Sigma_{b} \Sigma_{s}\left\{a+F_{t}\left(\beta_{1}-1\right)+\beta_{2} F_{t}{ }^{2}\right\} A_{b s}= \\
& =\alpha+\left(\beta_{1}-1\right) \bar{F}+\beta_{2}\left(\overline{F^{2}}\right) \Rightarrow\left(\beta_{1}-1\right) \bar{F}+\beta_{2}\left(\overline{F^{2}}\right)=\Delta F-a
\end{aligned}
$$

Vervolgens wordt afgeleid in welk punt de groei van het percentage vrouwen het grootst is. Noem dit $F_{M A X}$, zoals aangegeven in de figuur. Dit punt kan worden afgeleid door het maximaliseren van $\left(F_{t+1}-F_{t}\right)$. Door te differentiëren naar $F_{t}$ wordt verkregen:

$$
\begin{aligned}
& \delta\left(F_{t+1}-F_{t}\right) / \delta F_{t}=\delta\left\{\alpha+F_{t}\left(\beta_{1}-1\right)+\beta_{2} F_{t}{ }^{2}\right\} / \delta F_{t}=\left(\beta_{1}-1\right)+2 \beta_{2} F_{t}=0 \\
& \Rightarrow \beta_{1}=1-2 \beta_{2} F_{\text {MAX }}
\end{aligned}
$$


Er zijn nu twee vergelijkingen, met vier onbekenden $\left(\alpha, \beta_{1}, \beta_{2}\right.$ en $F_{\text {MAX }}$ ). Er zijn derhalve twee aanvullende veronderstellingen nodig om dit stelsel op te lossen. De waarde van a geeft aan het percentage vrouwen dat in het prognosejaar werkzaam zal zijn in beroepen en bedrijfstakken waar in het basisjaar alleen mannen werkzaam waren (zie de figuur en de eerste formule). Als eerste aanvullende veronderstelling kan de waarde van a worden "geprikt", bijv. op de helft van het landelijke stijgingspercentage. Ten tweede kan, uit symmetrie-overwegingen, worden veronderstelt dat waar in 1985 nog $100 \%$ vrouwen werkzaam waren (het punt $F_{t}=1$ ) in het prognosejaar 1992 nog maar $(1-a) * 100 \%$ vrouwen werkzaam zullen zijn. Voor $F_{t}=1$ geldt dan:

$F_{t+1}=\alpha+\beta_{1}+\beta_{2}=1-\alpha \Rightarrow \beta_{1}+\beta_{2}=1-2 \alpha$.

Waar $F_{t}=1$ treedt dus een fractie a mannen in, evenals er in beroepen waar in 1985 nog $100 \%$ mannen werkzaam zijn $\left(F_{t}=0\right)$ een fractie a vrouwen intreedt. Als alternatief voor een van beide veronderstellingen kan de waarde van $F_{\text {MAX }}$ worden "geprikt", op bijvoorbeeld het gemiddelde percentage vrouwen in de beroepsbevolking $(34 \%)$.

In onderstaande tabel zijn aan de hand van bovenstaande vergelijkingen en restricties de waarden van de parameters afgeleid. Aan de linkerzijde van de tabel staan de restricties (de "geprikte waarden"), aan de rechterzijde de berekende parameters.

Tabel 4. Simulatie van het percentage vrouwen

$$
\begin{array}{ll}
\alpha=0,5^{*} \Delta F ; F_{\text {MAX }}=\bar{F} & \beta_{1}=1,1064 ; \beta_{2}=-0,1364 \\
\alpha=0,5^{*} \Delta F ; \beta_{1}+\beta_{2}=1-2 \alpha & \beta_{1}=1,1700 ; \beta_{2}=-0,2000 ; F_{\text {MAX }}=0,425 \\
F_{\text {MAX }}=\bar{F} ; \beta_{1}+\beta_{2}=1-2 \alpha & \beta_{1}=1,1478 ; \beta_{2}=-0,1895 ; \alpha=0,021
\end{array}
$$

$\bar{F}=0,34 ; \Delta F=0,03$

Zoals uit de tabel blijkt is $\beta_{1}>1$ en $\beta_{2}<0$ (wat overeenstemt met het geschetste verband in figuur 1 ), onder verschillende restricties. In de eerste regel van de tabel is het beginpunt en het punt waar het maximale 
verschil tussen het percentage vrouwen in het prognose- en het basisjaar optreedt vastgelegd. Hieruit volgen dan de waarden voor $\beta_{1}$ en $\beta_{2}$. In de tweede rege 1 is het begin- en het eindpunt vastgelegd, in de derde regel het maximumpunt en het eindpunt. Als $\alpha=0,5^{*} \Delta \mathrm{F}=0,015$ volgt uit de tweede regel dat $F_{\text {MAX }}=0,425$. Als $F_{M A X}=\bar{F}=0,34$ volgt uit de derde regel dat $\alpha=$ 0,021 . Waarschijnlijk liggen de optimum-waarden voor $F_{M A X}$ in het interval $[0,34 ; 0,425]$ en voor $\alpha$ in het interval $[0,015 ; 0,021]$. Echter, de breedte van deze intervallen zijn vrij klein en het effect van verschillende waarden voor $\alpha$ en $F_{\text {MAX }}$ op $\beta_{1}$ en $\beta_{2}$ zijn gering. Omdat het grootste deel van de verandering van het percentage vrouwen plaatsvindt in het middengedeelte van de figuur, wordt bij de doorberekening van het percentage vrouwen naar het prognosejaar de variant gekozen waar het begin- en het eindpunt vastliggen en het maximumpunt vrij kan variëren (dit is de tweede regel uit de tabel).

Voor het doorrekenen van het model worden de resultaten gebruikt zoals die staan vermeld in tabel $3 B$ in bijlage 2. De berekening vindt plaats door de waarden voor de verklarende variabelen (het opleidingsniveau, het percentage vrouwen, de kapitaalintensiteit) in het prognosejaar te combineren met de gevonden regressiecoefficiënten uit tabe $13 B$. De waarden en coëfficiënten van de beroependummy's blijven ongewijzigd. De prognoses van het opleidingsniveau en de kapitaalintensiteit zijn ontleent aan een recente middellange-termijnraming van de ontwikkeling op de arbeidsmarkt tot 1992 , die is opgesteld ten behoeve van de arbeidsmarktmodule van het geautomatiseerde school- en beroepskeuze systeem ISee!. In onderstaande tabel zijn de simulatieresultaten vermeld voor het total en voor enkele beroepen met significante beroependummy's.

Uit onderstaande tabel blijkt dat de arbeidsduur (uigedrukt als fractie van de normale arbeidsduur in de bedrijfstak) tussen 1985 en 1992 gemiddeld ongeveer gelijk blijft. Dit komt doordat het effect van de stijging van het percentage vrouwen (wat resulteert in een daling van de arbeidsduur) voor een groot deel wordt gecompenseerd door een sterke stijging van het gemiddelde opleidingsniveau (wat resulteert in een stijging van de arbeidsduur). Binnen hetzelfde beroep blijkt de arbeidsduur echter wel te variëren over de verschillende bedrijfstakken, gezien de verschillen tussen de minimum- en maximumwarden in de arbeidsduur binnen eenzelfde beroep. 
Tabel 5. Simulatie-uitkomsten

\begin{tabular}{|c|c|c|c|c|c|c|}
\hline BEROEPa) & AD85 & MIN & MAX & AD92 & MIN & MAX \\
\hline $\begin{array}{l}1 \\
2 \\
3 \\
4 \\
5 \\
6 \\
7 \\
8 \\
9 \\
10 \\
11 \\
12 \\
13 \\
14 \\
15 \\
16 \\
17 \\
18 \\
19 \\
20 \\
21 \\
22 \\
23 \\
24 \\
25 \\
26 \\
27 \\
28 \\
29 \\
30 \\
31 \\
32 \\
34 \\
35 \\
36 \\
37 \\
38 \\
39 \\
40 \\
41 \\
42 \\
43 \\
44 \\
45 \\
46 \\
47 \\
48 \\
49 \\
50 \\
51 \\
52 \\
53\end{array}$ & $\begin{array}{r}.957 \\
.994 \\
1.012 \\
.960 \\
.902 \\
.995 \\
.983 \\
.993 \\
.954 \\
.867 \\
.973 \\
.926 \\
.937 \\
.782 \\
.688 \\
.912 \\
.810 \\
.993 \\
.997 \\
1.034 \\
.871 \\
.912 \\
.943 \\
1.000 \\
1.015 \\
.854 \\
.786 \\
.905 \\
.993 \\
1.024 \\
.969 \\
.971 \\
.995 \\
.993 \\
.941 \\
.847 \\
.833 \\
.922 \\
.982 \\
.961 \\
.810 \\
.674 \\
.549 \\
.855 \\
.838 \\
.975 \\
.876 \\
1.028 \\
.943 \\
.957 \\
1.019 \\
1.040\end{array}$ & $\begin{array}{l}.92 \\
.97 \\
.99 \\
.92 \\
.73 \\
.97 \\
.96 \\
.97 \\
.93 \\
.75 \\
.91 \\
.86 \\
.89 \\
.66 \\
.59 \\
.80 \\
.75 \\
.97 \\
.97 \\
1.00 \\
.80 \\
.83 \\
.79 \\
.97 \\
1.02 \\
.73 \\
.72 \\
.81 \\
.99 \\
1.00 \\
.96 \\
.97 \\
.97 \\
.96 \\
.85 \\
.53 \\
.79 \\
.87 \\
.96 \\
.93 \\
.63 \\
.54 \\
.33 \\
.84 \\
.74 \\
.90 \\
.75 \\
1.01 \\
.89 \\
.86 \\
1.00 \\
1.02\end{array}$ & $\begin{array}{r}1.01 \\
1.05 \\
1.06 \\
1.01 \\
.98 \\
1.06 \\
1.04 \\
1.05 \\
1.03 \\
.96 \\
1.02 \\
1.00 \\
1.00 \\
.96 \\
.80 \\
.99 \\
.87 \\
1.06 \\
1.06 \\
1.07 \\
.95 \\
1.01 \\
1.02 \\
1.06 \\
1.02 \\
.97 \\
.89 \\
.97 \\
.99 \\
1.05 \\
.98 \\
.97 \\
1.05 \\
1.05 \\
1.05 \\
.98 \\
.90 \\
.97 \\
1.00 \\
1.01 \\
.94 \\
.82 \\
.80 \\
.87 \\
.94 \\
1.07 \\
.99 \\
1.07 \\
1.00 \\
1.00 \\
1.06 \\
1.08\end{array}$ & $\begin{array}{r}.960 \\
.998 \\
1.002 \\
1.007 \\
.957 \\
1.009 \\
.992 \\
1.030 \\
.997 \\
.777 \\
.977 \\
.929 \\
.926 \\
.699 \\
.728 \\
.921 \\
.837 \\
1.005 \\
1.017 \\
1.059 \\
.870 \\
.909 \\
.947 \\
1.008 \\
1.016 \\
.821 \\
.783 \\
.911 \\
.997 \\
.887 \\
.942 \\
.971 \\
1.019 \\
.997 \\
.951 \\
.822 \\
.867 \\
.928 \\
1.019 \\
.993 \\
.785 \\
.589 \\
.498 \\
.852 \\
.888 \\
1.037 \\
.904 \\
1.029 \\
.934 \\
.931 \\
1.031 \\
1.041\end{array}$ & $\begin{array}{r}.85 \\
.96 \\
.94 \\
.89 \\
.86 \\
.91 \\
.91 \\
.99 \\
.91 \\
.72 \\
.96 \\
.84 \\
.81 \\
.66 \\
.65 \\
.85 \\
.81 \\
.97 \\
.87 \\
.97 \\
.86 \\
.80 \\
.86 \\
.96 \\
1.02 \\
.69 \\
.73 \\
.86 \\
1.00 \\
.82 \\
.92 \\
.97 \\
.96 \\
.97 \\
.86 \\
.72 \\
.81 \\
.78 \\
1.00 \\
.91 \\
.72 \\
.56 \\
.48 \\
.84 \\
.80 \\
.99 \\
.79 \\
1.02 \\
.86 \\
1.00 \\
.03\end{array}$ & $\begin{array}{r}1.04 \\
1.03 \\
1.06 \\
1.04 \\
1.12 \\
1.05 \\
1.04 \\
1.06 \\
1.06 \\
.84 \\
.99 \\
1.00 \\
1.00 \\
.75 \\
.81 \\
1.01 \\
.87 \\
1.03 \\
1.08 \\
1.12 \\
.88 \\
.99 \\
1.05 \\
1.04 \\
1.02 \\
.93 \\
.95 \\
.99 \\
1.00 \\
1.01 \\
.96 \\
.97 \\
1.06 \\
1.03 \\
1.01 \\
.95 \\
.91 \\
1.06 \\
1.04 \\
1.10 \\
.85 \\
.71 \\
.52 \\
.88 \\
1.000 \\
1.06 \\
.95 \\
1.04 \\
1.06\end{array}$ \\
\hline
\end{tabular}


$-25-$

\begin{tabular}{lrrrrrr}
54 & 1.026 & 1.03 & 1.03 & 1.038 & 1.04 & 1.04 \\
55 & .991 & .97 & 1.05 & .991 & .94 & 1.00 \\
56 & .999 & .97 & 1.03 & .994 & .99 & .99 \\
57 & .983 & .97 & .99 & .986 & .97 & .99 \\
58 & .993 & .97 & 1.02 & 1.026 & 1.00 & 1.08 \\
59 & .968 & .85 & 1.04 & .977 & .82 & 1.07 \\
60 & .980 & .97 & 1.00 & .977 & .93 & 1.02 \\
61 & 1.004 & 1.00 & 1.01 & 1.000 & .99 & 1.01 \\
62 & .988 & .93 & 1.06 & .942 & .80 & 1.00 \\
64 & .880 & .79 & .94 & .862 & .77 & 1.01 \\
65 & .848 & .58 & .98 & .932 & .87 & .97 \\
66 & .964 & .91 & .99 & .986 & .96 & 1.02 \\
67 & .989 & .99 & .99 & .985 & .96 & 1.01 \\
68 & .990 & .97 & 1.06 & .992 & .96 & 1.02 \\
69 & .989 & .97 & 1.05 & .988 & .94 & 1.01 \\
70 & .992 & .95 & 1.05 & .995 & .93 & 1.02 \\
71 & .967 & .94 & 1.01 & .962 & .95 & .98 \\
72 & .995 & .97 & 1.06 & .974 & .76 & 1.02 \\
73 & .920 & .87 & .96 & .934 & .88 & 1.00 \\
74 & .974 & .96 & 1.00 & 1.009 & .98 & 1.07 \\
75 & .974 & .96 & 1.02 & .951 & .80 & 1.01 \\
76 & .939 & .89 & 1.00 & .994 & .99 & 1.01 \\
77 & .981 & .94 & 1.04 & .975 & .91 & 1.02 \\
78 & .995 & .97 & 1.05 & .996 & .96 & 1.03 \\
79 & .950 & .92 & .99 & .954 & .89 & 1.03 \\
80 & .995 & .97 & 1.05 & 1.000 & .97 & 1.02 \\
81 & .993 & .97 & 1.05 & .994 & .98 & 1.01 \\
82 & .951 & .88 & 1.01 & .961 & .90 & 1.01 \\
83 & .976 & .93 & 1.02 & .983 & .96 & 1.01 \\
84 & .961 & .91 & 1.03 & .971 & .84 & 1.02 \\
Totaa1 & .898 & .33 & 1.08 & .896 & .48 & 1.11 \\
& & & & & & \\
\hline & & & & & &
\end{tabular}

a) Zie voor de beroepsnamen bijlage 1 . 


\section{CONCLUSIES EN SAMENVATTING}

In het eerste gedeelte van dit paper is een korte beschrijving gegeven van de ontwikkeling van de deeltijdarbeid als de voornaamste determinant van de gemiddelde arbeidsduur. Het blijkt dat de mate waarin in deeltijd wordt gewerkt het laatste decennium sterk is gestegen.

Vervolgens is door middel van een RAS-procedure voor elke combinatie van beroep en bedrijfstak op resp. de 3-digit ISCO-classificatie en 3-digit SBIclassificatie een schatting gemaakt van de verdeling van de werkzame personen naar arbeidsduurklassen, gegeven de verdeling van de arbeidsduur naar beroep (de horizontale randtotalen) en de verdeling van de arbeidsduur naar bedrijfstak (de verticale randtotalen). De uitkomsten van deze RASprocedure zijn gesommeerd naar gemiddelde arbeidsduren voor de 2-digit beroep- en bedrijfstakindeling.

Daarna werd voor deze arbeidsduren een model opgesteld, waarin de arbeidsduur werd verklaard uit bedrijfstakgrootheden (bezettingsgraad van de produktiecapaciteit, kapitaalintenstiteit) en andere grootheden zoals het opleidingsniveau en het percentage vrouwen, beide naar beroep en naar bedrijfstak. Daarnaast werden beroependummy's opgenomen, omdat de gemiddelde arbeidsduur voor een belangrijk deel samenhangt met het beroep. Er werd in de analyse rekening mee gehouden dat de normale arbeidsduur tussen verschillende bedrijfstakken kan verschillen. Bij de overheid is bijvoorbeeld door invoering van een algemene arbeidsduurverkorting de normale arbeidsduur korter dan in veel industriesectoren. Uit de schattingen van het model werd de conclusie getrokken dat naast de beroependummy's het percentage vrouwen en het opleidingsniveau de belangrijkste determinanten zijn van de arbeidsduur.

Tenslotte werd een simulatie uitgevoerd. Voor deze simulatie werden een aantal veronderstellingen gemaakt met name ten aanzien van het toekomstige percentage vrouwen in een beroep in een bedrijfstak. Het bleek dat de tegengestelde effecten van het sterk gestegen opleidingsniveau en het toegenomen percentage vrouwen op de gemiddelde arbeidsduur elkaar op middellange termijn in evenwicht houden.

De gemiddelde arbeidsduren verschillen zowel over de beroepen, als over de bedrijfstakken. Door gebruik te maken van de resultaten van deze analyse van de arbeidsduur kan de omrekening van arbeidsvolume naar werkzame personen 
worden gedifferentieërd naar zowel beroep als bedrijfstak. Met deze uitkomsten kunnen de prognoses van het aantal werkzame personen naar beroep en bedrijfstak derhalve nauwkeuriger worden verricht. 


\section{LITERATUUR}

Arbeidsduur nader bekeken, (1983), Nota arbeidsduur II van de Raad van de Centrale Ondernemingsorganisaties, s'Gravenhage.

Bacharach, M. (1970), Biproportional Matrices \& Input-Output Change, Cambridge University Press, Cambridge.

Bos, W., Overeengekomen jaarlijkse arbeidsduur, jaargemiddelde aantal banen en arbeidsvolume van werknemers, 1977-1986; methode en resultaten van een proefonderzoek, Supplement bij de Sociaal-Economiche Maandstatistiek, jaargang 1987 , no.5, CBS, Voorburg.

Dekker, R.J.P., A. de Grip en J.A.M. Heijke (ROA), Een verklaring van de beroepenstructuur van bedrijfstakken, Researchcentrum voor Onderwijs en Arbeidsmarkt, ROA-W-1988/2, Maastricht, 1988.

Delsen, L. (1986), Deeltijdarbeid: Mythe en Realiteit, Europees Centrum voor Werk en Samenleving, Maastricht.

Ginneken, C. van, Eindverslag van het onderzoek "De kwalitatieve structuur van de werkgelegenheid in het midden- en kleinbedrijf", Economisch Instituut voor het Midden en Kleinbedrijf, p. 168-178, september 1985, Zoetermeer.

Grip, A. de, J.A.M. Heijke, R.J.P. Dekker, L.F.M. Groot (ROA), De arbeidsmarkt naar beroep in 1992 en de positie van academici daarbinnen, Researchcentrum voor Onderwijs en Arbeidsmarkt, ROA-W-1987/1, Maastricht, 1987.

Hessemans, J.C.M., Ontwikkeling van de arbeidsduur 1982-1987: Enige uitkomsten van onderzoeken naar arbeidsduurverkorting, VUT en deeltijdarbeid, Supplement bij de Sociaal-Economische Maandstatistiek, jaargang 1988, no.3, p. 4-12, CBS, Voorburg.

Judge, G.G., R. Carter Hill, W.E. Griffiths, H. Lütkepoh1, T.C. Lee (1982), Introduction to the theory and practice of econometrics, Wiley, New York.

Judge, G.G., W.E. Griffiths, R. Carter Hill, T.C. Lee (1982), The theory and practice of econometrics, Wiley, New York.

Mourik, A. van, en J.J. Siegers, Ontwikkelingen in de beroepssegregatie tussen mannen en vrouwen, 1971-1985, Economisch Statistiche Berichten, $p$. $732-737,10$ augustus 1988.

Rapportage Arbeidsmarkt 1986, Ministerie van Sociale Zaken en Werkgelegenheid, p. 64-73, september 1986.

Rapport inzake werkgelegenheid en arbeidsduur, (1981), Stichting van de Arbeid, s'Gravenhage.

ROA, Naar een informatiesysteem onderwijs-arbeidsmarkt, onderzoeksprograma 1989/1990, ROA-rapport R-1989/1, Maastricht, 1989. 


\section{BIJLAGE 1: OVERZICHT VAN DE BEROEPENCODES EN DE BIJBEHORENDE BENAMING}

\section{BEROEP CODE BEROEPSKLASSE}

101

$202 / 03$

304

$4 \quad 05$

$5 \quad 06 / 07$

$6 \quad 08$

$7 \quad 09$

$8 \quad 11$

$9 \quad 12$

$10 \quad 13$

$11 \quad 14$

$12 \quad 15$

1316

$14 \quad 17$

$15 \quad 18$

$16 \quad 19$

1720

$18 \quad 21$

$19 \quad 30$

$20 \quad 31$

$21 \quad 32$

$22 \quad 33$

$23 \quad 34$

$24 \quad 35$

$25 \quad 36$

$26 \quad 37$

$27 \quad 38$

$28 \quad 39$

$29 \quad 40$

$30 \quad 41$

$31 \quad 42$

$32 \quad 43$

$33 \quad 44$

$34 \quad 45$

$35 \quad 46$

$36 \quad 47$

$37 \quad 48$

$38 \quad 49$

$39 \quad 50$

$40 \quad 51$

$41 \quad 52$

$42 \quad 53$

$43 \quad 54$

$44 \quad 55$

$45 \quad 56$

$46 \quad 57$

$47 \quad 58$

$48 \quad 59$

$49 \quad 60$

Schei-, natuurkundigen en verwante technici.

Architecten, ingenieurs en verwante tecnici, tekenaars.

V1iegtuig- en scheepsofficieren.

Biologen, biochemici, landbouwkundigen en verw. spec.

Genees- en tandheelkundigen, dierenartsen, verplegenden en verwante vakspecialisten.

Statistici, wiskundigen, systeemanalisten en verwante vakspecialisten.

Economen.

Accountants.

Juristen.

Leerkrachten.

Bedienaars van eredienst en verwante functies.

Auteurs, jounalisten e.d.

Beeldhouwers, kunstschilders, fotografen e.a. reatievekunstenaars.

Musici, toneelspelers e.a. uitvoerende kunstenaars.

Beroepssportlieden e.d.

Wetenschappelijke e.d. vakspecialisten n.e.g.

Beleidvoerende en hogere leidinggevende functies bij openbaar bestuur.

Beleidvoerende en hogere leidinggevende functies excl. openbaar bestuur.

Toezichthoudend-leidinggevend administratief personeel.

Uitvoerende hoofdambtenaren.

Secretaressen, typisten, ponstypisten e.d.

Boekhouders, kassiers en verwante functies.

Boekhoudmachine-, computerapparatuuroperateurs e.d.

Toezichthoudend-leidinggevend transport- en communicatiepersoneel.

Conducteurs trein, tram, bus e.d.

Post-distributiepersoneel.

Telefonisten, telegrafisten e.d.

Administratieve functies n.e.g.

Directeuren en bedrijfsleiders groothandel.

Directeuren en bedrijfsleiders detailhandel.

Zelfstandige groothandelaren en tussenpersonen.

Zelfstandige winkeliers

Zelfstandige detailhandelaren

Toezichthoudend-leidinggevend commercieel personeel, inkopers

Vertegenwoordigers, handel sagenten.

Verzekeringsagenten, makelaars e.a. tussenpersonen t.b.v. zakelijke diensten, veilinghouders e.d.

Winkelbedienden e.a. verkopers (excl. vertegenwoordigers).

Commerciële functies n.e.g.

Directeuren en bedrijfsleiders horecabedrijven.

Zelfstandige hotel-, restaurant-, caféhouders e.d.

Toezichthoudend-leidinggevend huishoudelijk personeel e.d.

Koks, kelners, buffetbediende e.d.

Huishoudelijk en verzorgend personeel n.e.g.

Huisbewaarders, schoonmaakpersoneel (gebouwen e.d.)

Wassers, persers e.d.

Kappers, schoonheidsspecialisten e.d.

Brandweer-, politiepersoneel, bewakers e.d.

Dienstverlenende functies n.e.g.

Bedrijfsleiders land- en tuinbouw e.d. 
Zelfstandige land- en tuinbouwers.

Agrarische arbeiders.

Boswachters en bosarbeiders, griendwerkers e.d.

Vissers, jagers e.d.

ISCO-beroepencode 680

Toezichthoudend-leidinggevend produktiepersonee 1 .

Mijn-, groeve-arbeiders, bronboorders e.d.

Hoogoven-, smeltovenarbeiders, walsers, gieters, vormers

e.a. metaalvervaardigende arbeiders.

Houtzagers, papiermakers e.d.

Chemische procesarbeiders en verwante functies.

Spinners, wevers, breiers, ververs en verwante functies.

Leerlooiers, pelsbereiders e.d.

Voedingsmiddelen- en drankenbereiders.

Tabaksbewerkers, tabaksproduktenmakers.

Kleermakers, kostuumnaaisters, stoffeerders en verwante

functies.

Schoenmakers, lederwarenmakers.

Meubelmakers e.a. houtbewerkers.

Steenhouwers, -zagers, -slijpers e.d.

Smeden, gereedschapmakers, machinale metaalbewerkers.

Machinebankwerker-monteurs, instrumentmakers, samenstellers en reparateurs van machines en apparaten (excl. elektr.).

Elektromonteurs, samenstellers en reparateurs van elektrische apparaten e.d.

Radio- en TV-zend-, geluids- beeldapparatuurbedieners.

Loodgieters, pijpfitters, lassers, plaat- en constructiewerkers.

Goud- en zilversmeden, diamantbewerkers e.d.

Glas-, aardewerkvormers en verwante functies.

Rubber- en plasticproductenmakers.

Papierwaren- en kartonnagewerkers.

Drukkers en verwante functies.

Schilders.

Ambachts- en industrieberoepen n.e.g.

Metselaars, timmerlieden e.a. bouwvakarbeiders.

Machinisten e.a. bedieners van stationaire machines en installaties.

Laders, lossers, inpakkers, grondwerk-, kraanmachinisten

Chauffeurs, matrozen, treinbestuurders en verwante functies.

Arbeiders n.e.g. 
BIJLAGE 2

Tabel 3B Schattingsresultaten arbeidsduurmodel

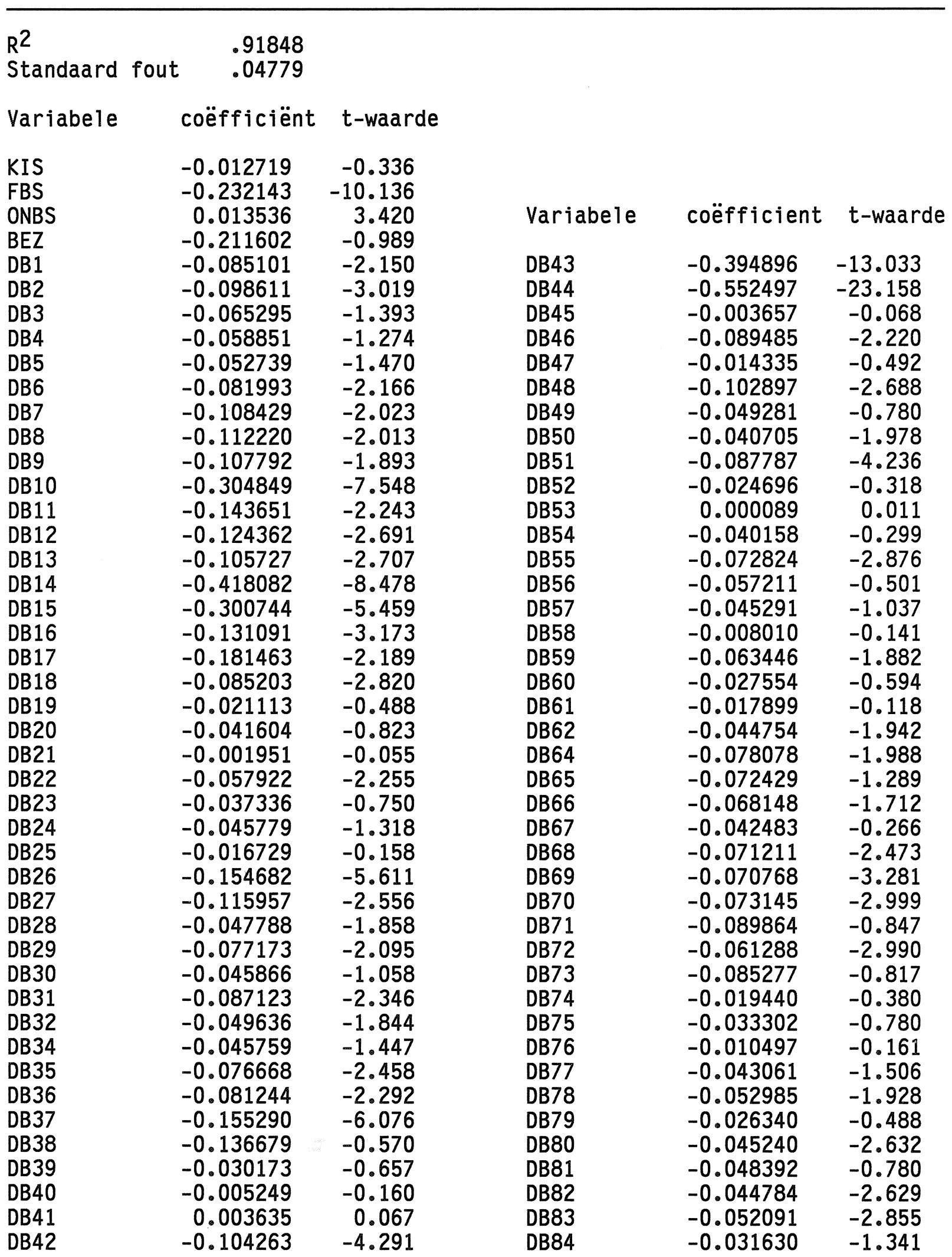




\section{APPENDIX}

De te schatten regressievergelijking luidde:

$\ln (\mathrm{HBS} / \mathrm{HS})=\Sigma b a_{b} \mathrm{DB}+\mu \mathrm{FBS}+\beta$ ONBS $+\tau$ KIS $+\theta$ BEZ

Deze kan worden herschreven tot

$y_{b s}=\alpha_{b}+\Sigma_{k=1} \beta_{k} x_{k}$

$$
\begin{aligned}
\text { waarbij } & y_{b s}=\ln (H B S / H S) ; \\
a_{b} & =\Sigma b a_{b} \text { DB; } \\
X_{k} & =(F B S, \text { ONBS, KIS, BEZ); } \\
b, s & =\text { beroep- en bedrijfstakindex. }
\end{aligned}
$$

In vectornotatie luidt deze vergelijking:

$$
y=\left[I_{B} \otimes \text { is }, X_{k}\right]\left(\begin{array}{l}
\alpha \\
\beta
\end{array}\right)
$$

$$
\begin{aligned}
\text { waarbij } & y=\left(y_{1}{ }^{\prime}, y_{2}{ }^{\prime}, \ldots, y_{B}{ }^{\prime}\right) \text { met } y_{b}{ }^{\prime}=\left(y_{b 1}, y_{b 2}, \ldots, y_{b S}\right) ; \\
I_{B} & =B \times B-\text { eenheidsmatrix; } \\
i_{S} & =S \times 1-v e c t o r \text { van enen; } \\
X_{k} & =\left(x_{k}, x_{k}, \ldots, x_{k B}\right) ; \\
\alpha & =\left(\alpha_{1}, \alpha_{2}, \ldots, \alpha_{B}\right) ; \\
\beta & =\left(\beta_{1}, \beta_{2}, \ldots, \beta_{k}\right) ; \\
\otimes & =\text { Kroneckerprodukt (zie Judge et al (1982), pp. 317-19) }
\end{aligned}
$$

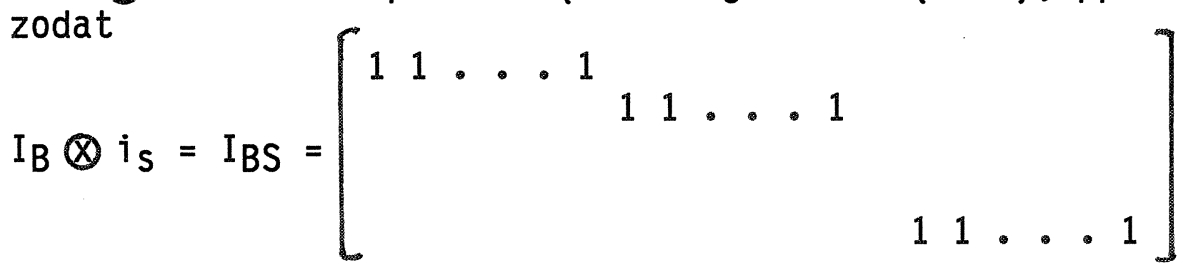

Tenslotte kan (3) herschreven worden als:

$y=Z \beta+\epsilon$

$\begin{aligned} \underset{\beta^{\prime}}{\text { waarbij }}=\left(\alpha^{\prime}, \beta_{k^{\prime}}\right) & \left.Z, X_{k}\right]\end{aligned}$

De veronderstelling die nu moet worden gemaakt om (4) met OLS te kunnen schatten zijn:

$E(\epsilon)=0$

$E\left(\varepsilon \epsilon^{\prime}\right)=\sigma_{\varepsilon}^{2} \cdot I_{B S}$.

Deze veronderstellingen houden in dat de storingsterm een verwachtingswaarde heeft gelijk aan nul, dat de variantie voor elke combinatie van beroep en bedrijfstak aan elkaar gelijk zijn en dat de covariantie tussen verschillende combinaties van beroepen en bedrijfstakken gelijk is aan nul. Indien aan deze voorwaarden is voldaan, dan is de OLS-schatter BLUE (Best Linear Unbiased Estimator). 